\title{
Front Matter: Volume 9768
}

, "Front Matter: Volume 9768," Proc. SPIE 9768, Light-Emitting Diodes:

Materials, Devices, and Applications for Solid State Lighting XX, 976801 (21 June 2016); doi: 10.1117/12.2239988

SPIE. Event: SPIE OPTO, 2016, San Francisco, California, United States 


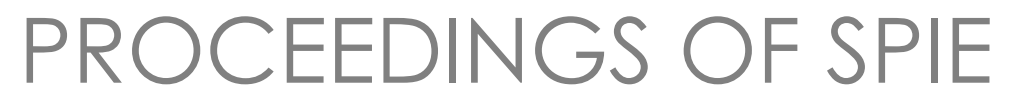

\title{
Light-Emitting Diodes: Materials, Devices, and Applications for Solid State Lighting $X X$
}

\author{
Heonsu Jeon \\ Li-Wei Tu \\ Michael R. Krames \\ Martin Strassburg \\ Editors
}

\section{5-17 February 2016}

San Francisco, California, United States

Sponsored and Published by

SPIE 
The papers in this volume were part of the technical conference cited on the cover and title page. Papers were selected and subject to review by the editors and conference program committee. Some conference presentations may not be available for publication. Additional papers and presentation recordings may be available online in the SPIE Digital Library at SPIEDigitallibrary.org.

The papers reflect the work and thoughts of the authors and are published herein as submitted. The publisher is not responsible for the validity of the information or for any outcomes resulting from reliance thereon.

Please use the following format to cite material from these proceedings:

Author(s), "Title of Paper," in Light-Emitting Diodes: Materials, Devices, and Applications for Solid State Lighting $X X$, edited by Heonsu Jeon, Li-Wei Tu, Michael R. Krames, Martin Strassburg, Proceedings of SPIE Vol. 9768 (SPIE, Bellingham, WA, 2016) Six-digit Article CID Number.

ISSN: 0277-786X

ISSN: 1996-756X (electronic)

ISBN: 9781510600034

Published by

SPIE

P.O. Box 10, Bellingham, Washington 98227-0010 USA

Telephone +1 3606763290 (Pacific Time) · Fax +1 3606471445

SPIE.org

Copyright (c) 2016, Society of Photo-Optical Instrumentation Engineers.

Copying of material in this book for internal or personal use, or for the internal or personal use of specific clients, beyond the fair use provisions granted by the U.S. Copyright Law is authorized by SPIE subject to payment of copying fees. The Transactional Reporting Service base fee for this volume is $\$ 18.00$ per article (or portion thereof), which should be paid directly to the Copyright Clearance Center (CCC), 222 Rosewood Drive, Danvers, MA 01923. Payment may also be made electronically through CCC Online at copyright.com. Other copying for republication, resale, advertising or promotion, or any form of systematic or multiple reproduction of any material in this book is prohibited except with permission in writing from the publisher. The CCC fee code is 0277-786X/16/\$18.00.

Printed in the United States of America.

Publication of record for individual papers is online in the SPIE Digital Library.

\section{SPIE. DIGITAL}

Paper Numbering: Proceedings of SPIE follow an e-First publication model. A unique citation identifier (CID) number is assigned to each article at the time of publication. Utilization of CIDs allows articles to be fully citable as soon as they are published online, and connects the same identifier to all online and print versions of the publication. SPIE uses a six-digit CID article numbering system structured as follows:

- The first four digits correspond to the SPIE volume number.

- The last two digits indicate publication order within the volume using a Base 36 numbering system employing both numerals and letters. These two-number sets start with $00,01,02,03,04$, $05,06,07,08,09,0 A, 0 B \ldots$ OZ, followed by 10-1Z, 20-2Z, etc. The CID Number appears on each page of the manuscript. 


\title{
Contents
}

\author{
vii Authors \\ ix Conference Committee
}

\section{NANOMATERIALS AND NANOSTRUCTURES FOR LEDS I}

976803 Estimation of free carrier concentrations in high-quality heavily doped GaN:Si micro-rods by photoluminescence and Raman spectroscopy [9768-2]

976805 Single-crystal phosphors for high-brightness white LEDs/LDs (Invited Paper) [9768-4]

UV/DUV-EMITTING LEDS

$97680 \mathrm{~A}$ Investigation of light output uniformity and performance using a UV transmitting glass optic for a multi-UV LED array [9768-9]

HIGH CURRENT PERFORMANCE AND DROOP IN INGAN LEDS

$97680 \mathrm{C}$ Light-emitting diodes for solid-state lighting: searching room for improvements (Invited Paper) [9768-11]

9768 OD Thermal droop in InGaN-based LEDs: physical origin and dependence on material properties [9768-12]

NOVEL TECHNOLOGIES FOR LED DESIGN AND FABRICATION I

9768 OK Emission characteristics of light-emitting diodes by confocal microscopy [9768-18]

NOVEL TECHNOLOGIES FOR LED DESIGN AND FABRICATION II

$97680 \mathrm{~N}$ Correlation between p-GaN growth environment with electrical and optical properties of blue LEDs [9768-21]

9768 OP Blue resonant-cavity light-emitting diode with half milliwatt output power [9768-23]

$97680 Q \quad$ Fabrication and characterization of broadband superluminescent diodes for $\mathbf{2} \boldsymbol{\mu m}$ wavelength [9768-24] 
NANOMATERIALS AND NANOSTRUCTURES FOR LEDS II

9768 OT Position-controlled MOVPE growth and electro-optical characterization of core-shell InGaN/GaN microrod LEDs (Invited Paper) [9768-27]

LED MANUFACTURING I

9768 OW Progress and challenges in GaN-on-Si LEDs (Invited Paper) [9768-30]

9768 0X Monolithic LED arrays, next generation smart lighting sources (Invited Paper) [9768-31]

9768 OY High-brightness low-power consumption microLED arrays [9768-32]

976810 LED light engine concept with ultra-high scalable luminance [9768-63]

LED APPLICATIONS AND SOLID-STATE LIGHTING

976811 Advances in LEDs for automotive applications (Invited Paper) [9768-34]

976813 3D structural construction of GaN-based light-emitting diode by confocal micro-Raman spectroscopy (Invited Paper) [9768-36]

976814 Progress in characterizing the multidimensional color quality properties of white LED light sources [9768-37]

976815 Adaptive multi-wavelength LED star simulator for space life studies [9768-38]

LED MANUFACTURING II

97681 A Process control of MOCVD growth for LEDs by in-situ photoluminescence (Invited Paper) [9768-43]

9768 ID Significant improvement of GaN crystal quality with ex-situ sputtered AIN nucleation layers [9768-46]

9768 1E Aging behavior, reliability, and failure physics of GaN-based optoelectronic components (Invited Paper) [9768-64]

NOVEL SUBSTRATES FOR LED EPISTRUCTURE GROWTH AND GREEN TO RED LEDS

$97681 G$ Development of semipolar (11-22) LEDs on GaN templates (Invited Paper) [9768-48]

976811 Room temperature green to red electroluminescence from (Al,Ga)As/GaP QDs and QWs [9768-50]

$97681 \mathrm{~J} \quad$ Red InGaP light-emitting diodes epitaxially grown on engineered Ge-on-Si substrates [9768-51] 
9768 IK AIGalnP red-emitting light emitting diode under extremely high pulsed pumping [9768-52]

POSTER SESSION

9768 1M Design and implementation of a deception jamming system for laser receivers [9768-54]

9768 IN Do we need to recalibrate our strategy in InGaN-on-SiC LED technology given its low efficiency? [9768-55]

$97681 Q \quad$ Epitaxial growth and photoluminescence properties of $\beta-\mathrm{FeSi}_{2}$ grains using liquid phase obtained by Au-Si eutectic reaction [9768-58]

9768 IR Modeling of novel hybrid photonic crystal structures involving cured hydrogen silsesquioxane pillars for improving the light extraction in light-emitting diodes [9768-60] 
Proc. of SPIE Vol. $9768976801-6$

Downloaded From: https://www.spiedigitallibrary.org/conference-proceedings-of-spie on 26 Apr 2023 Terms of Use: https://www.spiedigitallibrary.org/terms-of-use 


\section{Authors}

Numbers in the index correspond to the last two digits of the six-digit citation identifier (CID) article numbering system used in Proceedings of SPIE. The first four digits reflect the volume number. Base 36 numbering is employed for the last two digits and indicates the order of articles within the volume. Numbers start with 00, 01, 02, 03, 04, 05, 06, 07, 08, 09, OA, OB...0Z, followed by 10-12, 20-2Z, etc.

\author{
Akhter, M., 1G \\ Akiyama, Kensuke, 1Q \\ Arjoca, Stelian, 05 \\ Avramescu, A., 03, 0T \\ Bahgat, Ahmed Sami, $1 \mathrm{M}$ \\ Bao, Shuyu, 1J \\ Barbisan, Diego, 15 \\ Bertazzi, F., OD \\ Bhardwaj, Jy, 11 \\ Bonar, James R., OY \\ Bonato, Matteo, 15 \\ Bono, Hubert, OX \\ Bruls, Dominique, 10 \\ Brunner, F., 1A, 1G \\ Buffolo, Matteo, 1E \\ Caliebe, M., $1 G$ \\ Chang, Chiao-Yun, 13 \\ Chang, Chi-Chieh, OP \\ Chang, Yu-Ming, 13 \\ Chen, Shuo-Wei, 1D \\ Chen, Wei-Liang, 13 \\ Chen, YU-Ting, OP \\ Cheng, Hui-Yu, 13 \\ Cheung, W. S., OK \\ Choi, H. W., OK \\ Claudi, Riccardo U., 15 \\ Cocola, Lorenzo, 15 \\ Corbett, B., 1G \\ Dadgostar, Shabnam, 11 \\ Dawson, Jeremy M., IR \\ de Boer, Dick, 10 \\ De Santi, Carlo, OD, $1 \mathrm{E}$ \\ Dinh, D. V., $1 G$ \\ Dominici, S., OD \\ Dudelev, Vladislav V., IK \\ El-Sharkawy, Yaser H., $1 \mathrm{M}$ \\ El-Sherif, Ashraf F., 1M \\ Erculiani, Marco S., 15 \\ Fedorova, Ksenia A., ON \\ Fenwick, William, OW \\ Ferretti, Marco, 15 \\ Fitzgerald, Eugene A., $1 \mathrm{~J}$ \\ Forish, James, 0A \\ Funakubo, Hiroshi, 1Q \\ Galler, B., OD \\ Giro, Enrico, 15 \\ Goano, M., OD \\ Golz, Christian, 11 \\ Gong, Zheng, OY
}

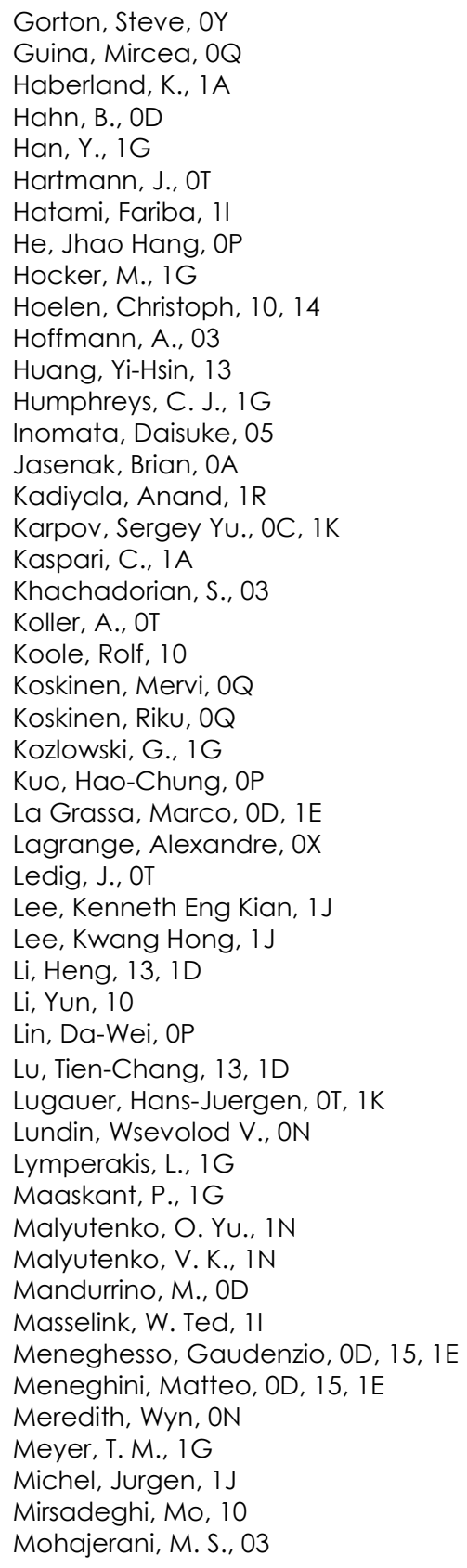


Monti, Desiree, $1 \mathrm{E}$

Nenstiel, C., 03

O'Mahony, D., $1 \mathrm{G}$

Parbrook, P., 1G

Peddada, Rao, 11

Pietzonka, Ines, $1 \mathrm{~K}$

Poletto, Luca, 15

Prall, C., 1A

Pristovsek, M., $1 G$

Quan, Z., 1G

Rafailov, Edik U., ON, $1 \mathrm{~K}$

Rueter, D., 1A

Sakharov, Alexey V., ON

Salasnich, Bernardo, 15

Schimpke, Tilman, 03, 0T

Scholz, F., IG

Schulz, S., 1G

Shimamura, Kiyoshi, 05

Slight, Thomas, ON

Small, James, OY

Soboleva, Ksenya K., $1 \mathrm{~K}$

Sokolovskii, Grigorii S., $1 \mathrm{~K}$

Spinger, Benno, 11

Strassburg, Martin, 03, 0T, 1K

Suomalainen, Soile, $\mathrm{OQ}$

Tan, Chuan Seng, $1 \mathrm{~J}$

Templier, François, OX

Teunissen, Kees, 14

Thonke, K., $1 \mathrm{G}$

Titkov, llya E., ON, 1K

Trivellin, Nicola, OD, 15, $1 \mathrm{E}$

Tsatsulnikov, Andrei F., ON

Valentine, Gareth J., OY

Van de Voorde, Patrick, 10

Van den Bergh, John-John, 10

van der Eyden, Joost, 10

Vanbroekhoven, Vincent, 10

Varghese, T., OT

Viheriälä, Jukka, $0 Q$

Víllora, Encarnación G., 05

Waag, A., 03, 0T

Wang, Bing, $1 \mathrm{~J}$

Wang, Cong, $1 \mathrm{~J}$

Wen, Wei-Chih, 1D

Weyers, M., 1A, $1 G$

Willsey, Adam, OA

Willsey, Rachel, OA

Wu, Chun Chia, OP

Yadav, Amit, ON, IK

Yang, Young, 1D

Yeh, Pinghui S., OP

Yoon, Soon Fatt, $1 \mathrm{~J}$

Zanoni, Enrico, OD, 15, 1E

Zeisel, R., OD

Zia, Nouman, $0 Q$

Zulonas, Modestas, ON 


\section{Conference Committee}

Symposium Chairs

Jean-Emmanuel Broquin, IMEP-LAHC (France)

Shibin Jiang, AdValue Photonics, Inc. (United States)

Symposium Co-chairs

David L. Andrews, University of East Anglia (United Kingdom)

Alexei L. Glebov, OptiGrate Corporation (United States)

Program Track Chair

Klaus P. Streubel, OSRAM AG (Germany)

Conference Chairs

Heonsu Jeon, Seoul National University (Korea, Republic of)

Li-Wei Tu, National Sun Yat-Sen University (Taiwan)

Michael R. Krames, Arkesso, LLC (United States)

Martin Strassburg, OSRAM Opto Semiconductors GmbH (Germany)

Conference Program Committee

Gerd Bacher, Universität Duisburg-Essen (Germany)

Mitch M. C. Chou, National Sun Yat-Sen University (Taiwan)

Michael Heuken, AIXTRON SE (Germany)

Christoph Hoelen, Philips Lighting B.V. (Netherlands)

Satoshi Kamiyama, Meijo University (Japan)

Jong Kyu Kim, Pohang University of Science and Technology

(Korea, Republic of)

Markus Klein, OSRAM Opto Semiconductors GmbH (Germany)

Kei May Lau, Hong Kong University of Science and Technology

(Hong Kong, China)

Kurt J. Linden, N2 Biomedical (United States)

Tien-Chang Lu, National Chiao Tung University (Taiwan)

Joongseo Park, LG Electronics Inc. (Korea, Republic of)

E. Fred Schubert, Rensselaer Polytechnic Institute (United States)

Ross P. Stanley, Centre Suisse d'Electronique et de Microtechnique SA

(Switzerland)

Klaus P. Streubel, OSRAM AG (Germany)

Tetsuya Takeuchi, Meijo University (Japan)

Dong-Sing Wuu, National Chung Hsing University (Taiwan) 
Session Chairs

1 Nanomaterials and Nanostructures for LEDs I

Martin Strassburg, OSRAM Opto Semiconductors GmbH (Germany)

2 UV/DUV-Emitting LEDs

Michael Kneissl, Technische Universität Berlin (Germany)

3 High Current Performance and Droop in InGaN LEDs

Michael R. Krames, Arkesso, LLC (United States)

4 Novel Technologies for LED Design and Fabrication I

Aurelien David, Soraa, Inc. (United States)

5 Novel Technologies for LED Design and Fabrication II

Tien-Chang Lu, National Chiao Tung University (Taiwan)

Li-Wei Tu, National Sun Yat-Sen University (Taiwan)

6 Nanomaterials and Nanostructures for LEDs II

Andreas Waag, Technische Universität Braunschweig (Germany)

7 LED Manufacturing I

Chih-Chung Yang, National Taiwan University (Taiwan)

8 LED Applications and Solid-State Lighting

Michael R. Krames, Arkesso, LLC (United States)

9 Nanomaterials and Nanostructures for LEDs III

Martin Strassburg, OSRAM Opto Semiconductors GmbH (Germany)

10 LED Manufacturing II

William Fenwick, Toshiba America Electronic Components, Inc. (United States)

11 Novel Substrates for LED Epistructure Growth and Green to Red LEDs Axel Hoffmann, Technische Universität Berlin (Germany) 